\title{
Cattle Grazing and Behavior on a Forested
} Range

\author{
LEONARD ROY ROATH AND WILLIAM C. KRUEGER
}

\begin{abstract}
Environmental and topographic parameters on a mountainous forested range were analyzed to establish causes of cattle behavioral responses. Distinct home range groups of cattle were identified through examination of quality and patterns of forage use, cattle distribution, herd social structure, and cattle activities. The home range of one group encompassed only upland areas. Water and vegetation type were important parameters in determining area and degree of use. Vertical distance above water was the most important factor in determining vegetation utilization on moderately steep slopes. Time after sunrise and relative humidity factors were key factors in determining kind and timing of cattle activity.
\end{abstract}

Cattle have been grazing forested ranges in western United States for more than 125 years (United States Senate 1936). Grazing units on the forests have been fenced, restricting livestock to given areas. Fencing placed definite limits on forage and often increased animal concentration on key vegetation types. Some vegetation types were over-utilized while others were left ungrazed.

As the demand for more and varied uses of mountain land areas increases, it becomes important to enhance livestock distribution, alleviating concentration problems and minimizing real or potential conflicts with other resource uses. Detailed information assessing the pattern of livestock use, the types and amounts of forage consumed, and livestock distribution is required. This is only baseline information; in order to apply it, one must know the cause and the mechanism of each parameter.

Determining causes for observed actions of cattle overlaps range management and applied behavioral sciences. External physical and biotic influences interact with the animal's innate behavioral complex to produce a given response. Measurement of influencing parameters must be matched with the animal response and examined to establish the cause and effect relationship. Distance from water, topography, temperature, humidity, and forage availability have been rated as important parameters in modifying animal behavior. Herd structure is a behavioral factor which could have considerable influence on grazing patterns and forage use. Many researchers have observed a given event and assessed the impact on vegetation, but those observations were often not analyzed in terms of what caused the event.

This research was designed to quantitatively define the influences of topography, environment and biotic factors on cattle distribution and grazing habits. Cattle behavioral responses to external factors were described by regression relationships.

\section{Study Area Description}

\section{Research was conducted on a unit of a Forest Service allotment}

\footnotetext{
Authors were, at the time of the research, graduate student and head Rangeland Resources Program, Oregon State University, Corvallis, 97331. Roath is now assistant professor. Department of Range Science. Texas A\&M University. College Station, 77843. The authors thank the staff of the Malheur National Forest and Ranchers William and Jack Southworth for their cooperation throughout this study.

Submitted as Technical Paper No. 5566. Oregon Agricultural Experiment Station, Corvallis.

This research was jointly funded by the Oregon Agricultural Experiment Station and Pacific Northwest Forest and Range Experiment Station.

Manuscript received July $19,1980$.
}

on forested mountainous range in the southern Blue Mountains of Oregon. The unit consisted of 2656.5 ha of primarily forested land, and was bisected by a permanent stream. Topography was steep adjacent to the bluegrass bottoms and gentle-to-moderately rough in upland areas. Elevation on the unit ranged from 1440 to $1800 \mathrm{~m}$. Precipitation consists of deep winter snows, especially on the higher elevations, with some rain during spring, and dry summers. Precipitation ranges from approximately $36 \mathrm{~cm}$ per year on the lower elevations to over $60 \mathrm{~cm}$ per year at higher elevations (Carlson 1974). Upland areas have moderate soil depths. The horizon consists of $11-30 \mathrm{~cm}$ of volcanic ash with 7-25 cm clay subsoils beneath. Rock outcrops are frequent. The lowlands are bluegrass bottoms with characteristic silt loams on the flood plain.

Ten vegetation types were identified on the area, but only eight supported reasonable amounts of grazing (Fig. 1). The bluegrass bottoms type was characterized by Kentucky bluegrass (Poa pratensis), sedges (Carex spp.) and a great many forbs including cinquefoil (Potentilla spp.), camas (Camasia spp.), western yarrow (Achillea millefolium), and many others. Columbia needlegrass (Stipa columbiana), slender wheatgrass (Agropyron trachycaulum), and mountain brome (Bromus marginatus) were also present on the riparian type but did not constitute a substantial component of the total biomass.

The sagebrush (Artemisia tridentata spp. vaseyana), Sand berg bluegrass (Poa sandbergii) type had mountain big sagebrush and Sandberg bluegrass as the most prominent plant species in the type. Mountain big sagebrush also served as an overstory dominant with bluebunch wheatgrass (Agropyron spicatum) as the herbaceous dominant on the steep south slopes. This type had characteristic slopes of $30-70 \%$.

Idaho fescue (Festuca idahoensis) and bluebunch wheatgrass were the dominant grasses under mountain big sagebrush on the open hills. The open hills type occupied rolling upland areas where conifers were precluded because of the south-southwest exposure.

Pine (Pine ponderosa) upland Douglas fir (Pseudot suga menziesii) types were interspersed. The pine type occupied the level or gently rolling upland areas having slopes of $0-15 \%$, with Douglas fir dominating on the steeper aspects. Slopes of $10-40 \%$ were common in this type. Ponderosa pine was the dominant overstory in the pine upland, with elk sedge (Carex geyeri) and pinegrass (Calamogrostis rubescens) in the understory. Heartleaf arnica (Arnica cordifolia) was the primary forb in this type. The Douglas fir type showed the same basic understory dominants, but Douglas fir was the overstory tree. Coniferous canopy cover averaged $57 \%$.

The pine-bitterbrush (Purshia tridentata) type had shallower rocky soils with slopes ranging from $0-15 \%$. This community, in addition to the conifer canopy cover of $36 \%$, had an intermediate shrub layer of bitterbrush. Elk sedge was more sparse and was accompanied by western needlegrass (Stipa occidentalis) as well as heartleaf arnica in the herbaceous layer. The pine-bluebunch wheatgrass type was found at mid-elevations on south exposure slopes ranging from 20-60\%. Soils were thin and rocky. Pine was dispersed through this type with bitterbrush and bluebunch wheatgrass providing the understory components. 


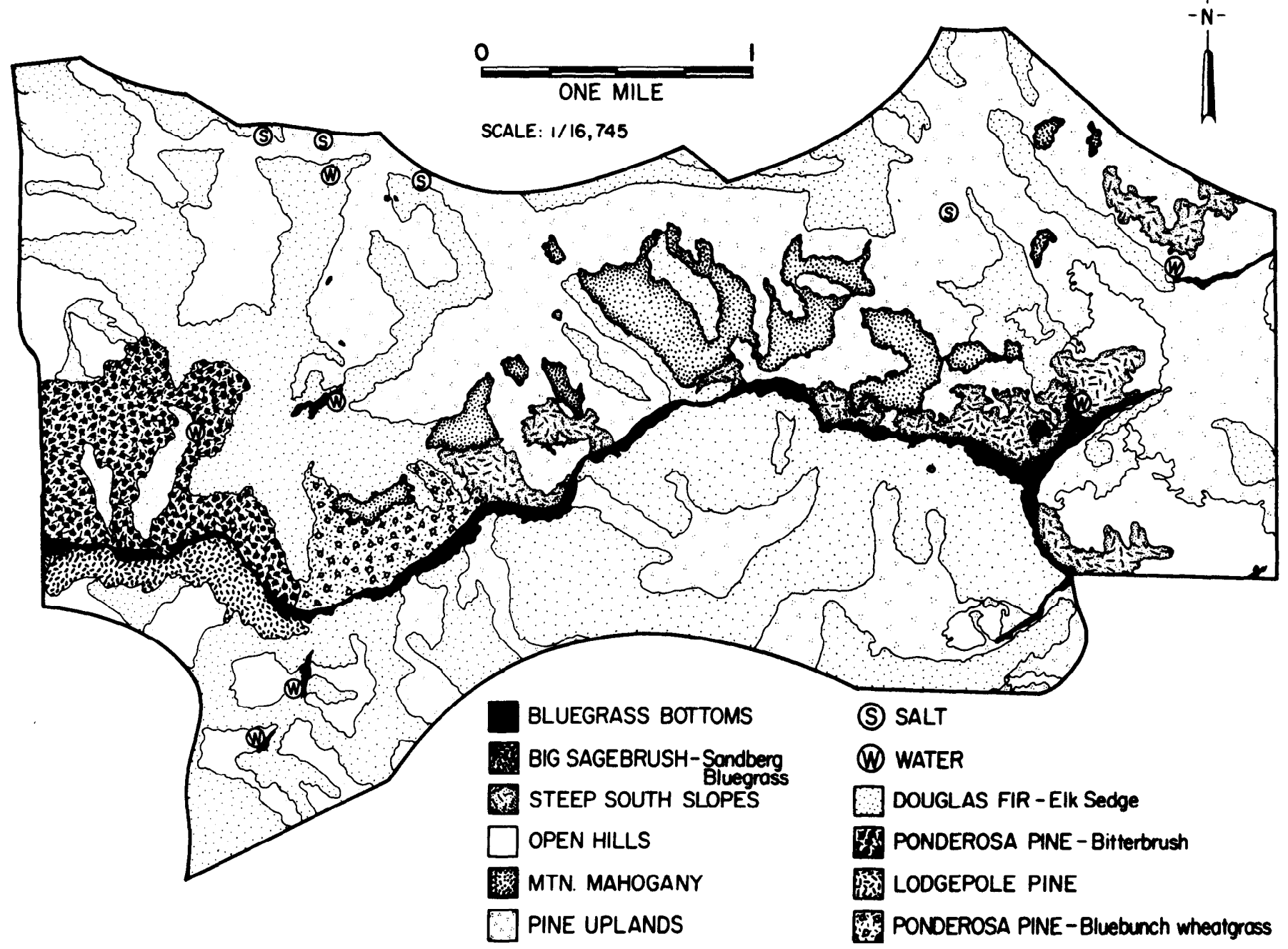

Fig. 1. Vegetation types of the study area.

Grazing seasons on the study unit were initiated on June 29 and June 23 in 1977 and 1978, respectively. Two hundred fifty crossbred cow-calf pair of primarily Hereford, Angus, and Shorthorn backgrounds grazed the unit both years. All cattle were individually marked with a freeze brand. Precipitation was below normal in 1977, resulting in early plant maturity and dessication. Many catchment type watering areas and seeps which cattle normally used were dry, severely restricting available water on the unit. Precipitation was normal or slightly above during 1978, resulting in a longer duration of lush forage and greater water availability.

\section{Methods and Procedures}

Vegetation used by livestock was accounted for by utilization estimates combined with forage production measurements for two successive seasons, 1977 and 1978 . Forage production by species was measured on the uplands employing the double-sampling technique described by Wilm et al. (1944). Ten estimates of onehalf square meter rectangular plots for each of three transects were made in each vegetation type. Two correction plots per transect were clipped to ground level. Percentage utilization estimates by weight were made at the end of the grazing season. Average utilization was estimated, as was distribution of utilization in relationship to measured distance from water, distance from salt, and elevation.

Forage removal on the riparian area was measured using sequential double-sampling throughout the grazing season. Onequarter square meter plots were used on the riparian area and 15 movable cages were employed to correct for regrowth.

Detailed observations of cattle numbers and cattle movements were collected throughout the grazing season. A minimum of two observations per week were taken in 1977 and a minimum of three per week in 1978. Time of cattle movements, locations, and activities were recorded.

Environmental observations of temperature and relative humidity were accumulated from six hygrothermograph locations, three on uplands and three on the riparian zone. Grazing season precipitation events were measured at two rain gauge stations. Barometric pressure was recorded with an altimeter barometer once per day at the same location to obtain consistent readings.

Analysis of variance was employed to test differences in forage utilization between years. Regression techniques and discriminate analysis were used to quantify climatic, vegetation. and topographic influences on livestock movement and behavior. Significance was based on $P \leq .05$ level unless otherwise specified.

\section{Results and Discussion}

\section{Vegetation Types and Forage Use}

Cattle use on mountainous habitats is controlled by an interaction of factors including topography, vegetation type, climate. availability of water, and livestock behavior. Only 922.1 ha of the unit were grazed, representing $35 \%$ of the land area available (Table 1). Obviously, livestock dispersion on the unit was not uniform on vegetation types or land area (Fig. 2). The blucgrass 
Table 1. Areas and percentages for the vegetation types on the Camp Creek Unit.

\begin{tabular}{|c|c|c|c|c|c|}
\hline Vegetation types & Area (ha) & $\%$ of Area & $\begin{array}{r}\% \text { Vegetation } \\
\text { type grazed }\end{array}$ & $\begin{array}{r}\text { Area grazed/veg. } \\
\text { type (ha) }\end{array}$ & $\begin{array}{r}\% \text { Grazed areas } \\
\text { contributed by } \\
\text { veg. type } \\
\end{array}$ \\
\hline Riparian zone & 49.4 & 1.9 & 100 & 49.4 & 5.4 \\
\hline Sagebrush-sandberg bluegrass & 7.7 & 0.3 & 100 & 7.7 & 0.8 \\
\hline Stecp south slopes & 122.8 & 4.6 & 47 & 57.7 & 6.3 \\
\hline Open hills & 95.8 & 3.6 & 46 & 44.1 & 4.8 \\
\hline Pine-bluebunch wheatgrass & 49.9 & 1.9 & 55 & 27.4 & 3.0 \\
\hline Pine-bitterbrush & 125.2 & 4.7 & 75 & 93.9 & 10.2 \\
\hline Pine uplands & 1042.6 & 39.2 & 42 & 437.9 & 47.5 \\
\hline Douglas fir-elk sedge & 1005.9 & 37.9 & 20 & 201.2 & 21.8 \\
\hline Lodgepole pine & 38.7 & 1.5 & 1 & 0.4 & $\mathrm{t}$ \\
\hline Mountain mahogany & 118.5 & 4.5 & 2 & 2.4 & $\mathrm{t}$ \\
\hline Total & 2656.5 & & & 922.1 & 34.7 \\
\hline
\end{tabular}

bottoms comprised $1.9 \%$ of the total area on the allotment but constituted $5.4 \%$ of the land area grazed. The vegetation types which were grazed generally represented a larger proportion of the area grazed than of the total area available. This indicated preferential use of some vegetation types.

Forage consumption per ha on the bluegrass bottoms was far greater than on any other type. This reflected difference in forage availability, time spent on the area and lack of physical constraints to grazing. The proportion of forage consumption provided may be an indication of the contribution of each type to livestock grazing. The bluegrass bottoms, which contributed $21 \%$ of the total herbaceous biomass produced on the unit, provided $81 \%$ of the forage consumed in both 1977 and 1978. The sagebrushSandberg bluegrass type adjacent to the bluegrass bottoms were used more than the upland vegetation types. This type had very gentle slopes and was close to water. The yield on the sagebrushSandberg bluegrass type was only about $500 \mathrm{~kg} / \mathrm{ha}$. Presumably, greater forage availability on this type would have greatly changed its percentage contribution to the total forage resource. Vegetation types adjacent to the bluegrass bottoms had a larger percentage of their area used than upland types. Cook's (1966) findings were similar. As will be later demonstrated, use on these types was probably influenced by their accessibility and relatively low elevations above water. However, there was no evidence that amount of

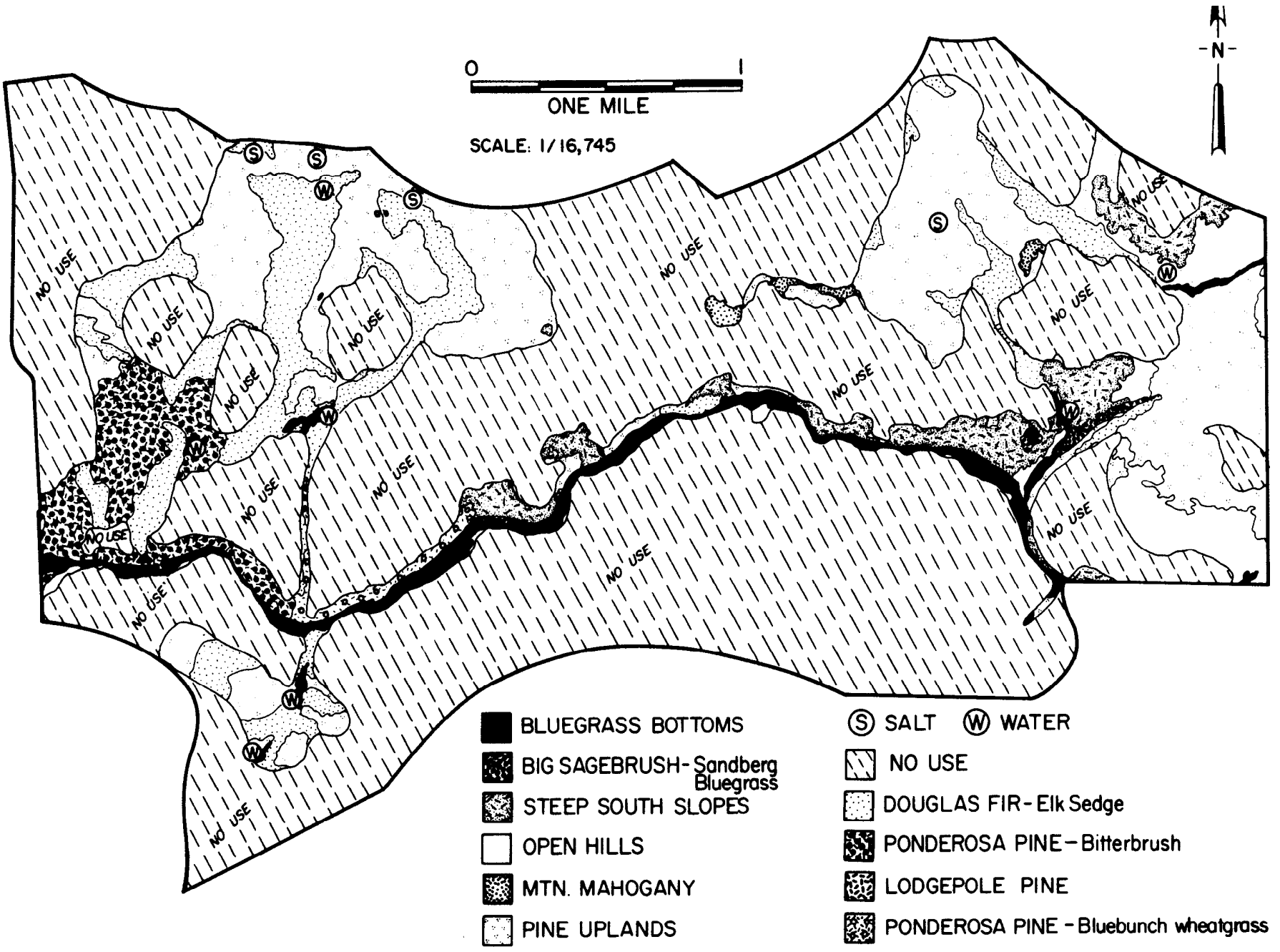

Fig. 2. Vegetation types grazed on the Camp Creek unit. 
Table 2. Forage consumption and percentage contribution of each vegetation type to total forage use on the Camp Creek Unit.

\begin{tabular}{|c|c|c|c|c|c|c|}
\hline & \multicolumn{3}{|c|}{1977} & \multicolumn{3}{|c|}{1978} \\
\hline & $\mathrm{kg} / \mathrm{ha}$ consumed & Ha grazed & $\begin{array}{r}\% \text { Total forage } \\
\text { use/type }\end{array}$ & kg/ha consumed & Ha grazed & $\begin{array}{r}\% \text { Total forage } \\
\text { use/type }\end{array}$ \\
\hline Riparian zone & 1937 & 49.4 & 81 & 2198 & 49.4 & 81 \\
\hline Pine uplands & 30 & 2137.9 & 11 & 40 & 437.9 & 13 \\
\hline Douglas fir-elk sedge & 20 & 201.2 & 3 & 20 & 201.2 & 3 \\
\hline Steep south slopes & 50 & 57.5 & 2 & 30 & 57.7 & 1 \\
\hline Open hills & $10^{1}$ & 44.1 & $\mathbf{T}$ & $10^{1}$ & 44.1 & $\mathrm{~T}$ \\
\hline Pine-bitterbrush & 101 & 93.9 & 1 & 15 & 93.9 & 1 \\
\hline Pine-bluebunch wheatgrass & $10^{1}$ & 27.4 & $\mathbf{T}$ & $10^{1}$ & 27.4 & $\mathrm{~T}$ \\
\hline Sagebrush-Sandberg bluegrass & $80^{\prime}$ & 7.7 & 1 & 83 & 7.7 & 1 \\
\hline
\end{tabular}

'Estimated values based on reconnaissance

utilization on the riparian zone directly affected utilization on these adjacent vegetation types. This agrees with the findings of Patton (1971) and Phillips (1965).

Consumption of vegetation on upland types tended to be low. The pine-bitterbrush type, which had $75 \%$ of its area grazed (Table 1 ), received very low use per ha (Table 2). Cattle dispersed widely over the type but spent little time grazing. This was also true for the open hills and pine-bluebunch wheatgrass types. These types contributed small percentages of the total vegetation use and were considered to be relatively unimportant in relation to other types. The pine upland type produced 11 and $13 \%$ of the forage consumed in 1977 and 1978, respectively, and was the most important upland type for grazing. The Douglas fir-elk sedge type comprised the greatest percentage of the land area, about $38 \%$, but produced only 3\% of the forage consumed in 1977 and 1978.

The pine upland had an open canopy cover and gentle terrain. This type and the pine-bitterbrush type had similar terrain and canopy cover; however, cattle used the pine uplands type much more than the pine-bitterbrush. This difference in use was reflected both by amount of vegetation consumed per ha (Table 2) and by number of animals observed in the type. Similar results were found by Clary et al. (1978) in Northern Arizona. The Dougas fir-elk sedge type received more use near water, but use rapidly decreased with distance away from water. This probably resulted from a combination of factors: primarily steep slopes common to the site; closed overstory canopy; north and west aspects of the type; and sparse understory vegetation. Hedrick et al. (1968) and Miller and Krueger (1976) found that a combination of overstory canopy cover and the amount of herbaceous vegetation in the understory were prominent factors in determining use on mixed coniferous forests. Miller and Krueger (1976) found that tree canopy cover accounted for $98 \%$ of the variation in herbaceous plant yield in the understory. The lodgepole pine and the portions of the Douglas fir type which had a north aspect received negligible amounts of use. Gonzalez (1964) and Van Vuren (1979) reported in research done in Utah, that northerly aspects were avoided by cattle. Extreme slopes of the mountain mahogany and lodgepole pine types also, apparently precluded cattle use.

Regression analysis revealed that correlations of linear distance away from water and salt with herbage utilization were low, but the square root transformations of distance from salt accounted for $64 \%$ of the variation in utilization, while $38 \%$ of the variation in utilization was accounted for by the square root of the distance from water (Table 3). Combining the two parameters in a multiple regression resulted in a relationship accounting for $62 \%$ of the variation in utilization. The partial correlation coefficients were -0.53 and 0.80 for water and salt, respectively.

The linear model using distance from salt accounted for a reasonable amount of variation in herbage utilization; however, the effect of distance from salt was confounded by the effect of preferred vegetation type.

Observations of cattle movements in 1977 and 1978 provided evidence about the effect of vegetation type on utilization. A pine uplands area was grazed with approximately equal intensity in 1977 and 1978, even though salt was in the area only in 1978. Therefore, it would seem that utilization of that type would be more controlled by vegetation type preference than desire for salt. The confounding effect of preferred vegetation type also influenced the relationship between utilization and distance from water (Table 3, Rep. 1). Apparently the cattle were willing to travel a greater initial distance to graze in that vegetation type. The moderate amount of variation accounted for by the multiple regression

Table 3 .Utilization on perennial grasses in relationship to distance from salt and water.

\begin{tabular}{|c|c|c|c|c|c|c|c|c|}
\hline \multicolumn{3}{|c|}{ Rep. 1} & \multicolumn{3}{|c|}{ Rep. 2} & \multicolumn{3}{|c|}{ Rep. 3} \\
\hline$\%$ Util & $\begin{array}{c}\text { Distance } \\
\text { from } \\
\text { water (m) }\end{array}$ & $\begin{array}{c}\text { Distance } \\
\text { from } \\
\text { salt }(\mathrm{m})\end{array}$ & $\%$ Util & $\begin{array}{c}\text { Distance } \\
\text { from } \\
\text { water }(m)\end{array}$ & $\begin{array}{c}\text { Distance } \\
\text { from } \\
\text { salt (m) }\end{array}$ & $\%$ Util & $\begin{array}{c}\text { Distance } \\
\text { from } \\
\text { water }(\mathrm{m})\end{array}$ & $\begin{array}{l}\text { Distance } \\
\text { from } \\
\text { salt }(\mathrm{m})\end{array}$ \\
\hline 35 & 1490 & 5 & 27 & 665 & 5 & 30 & 725 & 70 \\
\hline 15 & 1530 & 50 & 15 & 710 & 50 & 20 & 826 & 125 \\
\hline 15 & 1680 & 200 & 15 & 860 & 200 & 20 & 1180 & 600 \\
\hline 12 & 1780 & 400 & 12 & 1160 & 500 & 15 & 1360 & 835 \\
\hline 1 & 2000 & 935 & 1 & 1540 & 880 & 1 & 1540 & 1070 \\
\hline
\end{tabular}

Mulitiple Regression Model

\begin{tabular}{|c|c|}
\hline $\begin{array}{l}\hat{y}=-0.202 \sqrt{X_{1}}-0.695 \sqrt{ } \bar{X}_{2}+34.525 \\
X_{1}=\text { distance from water } \\
X_{2}=\text { distance from salt }\end{array}$ & $\begin{aligned} R^{2} & =0.624 t=4.64 * * \\
r x_{1} & =-0.534 \\
r x_{2} & =-0.804 \\
r x_{1} x_{2} & =0.556\end{aligned}$ \\
\hline
\end{tabular}

Linear Regression Models

Distance from salt $\hat{\mathrm{y}}=30.26-0.84 \sqrt{\mathrm{X}} \quad R^{2}=0.644 \quad t=4.88^{* *} \quad R .0001$

Distance from Water $\hat{\mathrm{y}} 40.44-0.75 \sqrt{\bar{X}} \quad R^{2}=P<.01 \quad t=3.23^{* *} \quad P<.01$ 
model indicated that unmeasured factors influence the amount of utilization an area receives. Miller and Krueger (1976) reported distance from salt and water accounted for $72 \%$ of the variability in vegetation use on a pasture with gentle terrain. Cook (1966) found he could only account for about $52 \%$ of the variability in livestock use with 21 measured parameters. He concluded patterns of previous use on the a rea were the best way to predict future use on that unit.

Observation of the cattle indicated that they were using slopes adjacent to the riparian zone on the contour. When the slopes were steep, the cattle grazed relatively close to the stream, but as the slope decreased the cattle grazed farther away.

Measurements of utilization versus vertical rise (Table 4) demonstrated that utilization approached zero at $80 \mathrm{~m}$ or more on vertical rise above the stream level. Regression analysis of utilization in 1977 and 1978 on the primary bunchgrass species revealed that 94 and $82 \%$ of the variation in bluebunch wheatgrass and basin wildrye use, respectively, were accounted for by vertical distance above the stream. Van Vuren (1979) indicated the same relationship for cattle in Utah mountain range. Calculations of vertical rise from Mueggler (1965) also suggested this relationship. The relationship between vertical rise above water and utilization on gentle slopes is poor. There may be a slope threshold value at which vertical rise above water replaces distance from water as the limiting factor on cattle distribution away from the water source. More extensive measurements would be required to make any prediction of that threshold value. Slopes in excess of $60 \%$ were not used by cattle regardless of vegetation type or aspect.

\section{Livestock Distribution}

Observations of cattle distribution on the unit indicated that water was a primary factor in determining cattle use of an area. During a year of below average precipitation, 1977, when many sources of water were dry, livestock use in those areas was lower than in 1978 when water was more available. The areas that were not utilized frequently in 1977 tended to be farther away from water than those areas receiving more frequent use. Water appeared to be the central point of distribution, with all the animals returning to a watering area at least once per day.

Salt was used regularly by livestock in both years. However, there was a pronounced difference in the pattern of livestock movements to and from salt. In 1977, the dry year, cattle trailed to salt from areas near water, then trailed back to water. Cattle were not observed to bed near the salting areas. In 1978, the vegetation was succulent later in the season, and water was more widely distributed on the unit. Cattle in that year often bedded in the vicinity of the salt block, remaining in the area several hours.

Distance from water did not have a strong influence on utilization; however, it is important to note that the distances from water at which vegetation utilization approached zero, about $1900 \mathrm{~m}$, were similar within the pine upland type. Apparently, when other influencing factors do not limit cattle distribution, distance from water ultimately controls the limit of vegetation utilization. Hodder and Low (1978) indicated that in Australia, water controlled the distance cattle would travel to utilize forage. In other vegetation types, and in steeper terrain, distances from water to where the utilization approached zero were much shorter.

The study unit had been previously logged, leaving a network of logging roads and skid trails. Cattle used logging roads extensively

Table 4. Utilization on species as affected by vertical distance above water.

\begin{tabular}{llllll}
\hline \hline & Species & 35 & 50 & 75 & $>80$ \\
\hline 1977 & Bluebunch wheatgrass & 55 & 45 & 20 & $<1$ \\
& Basin wildrye & 25 & 20 & 10 & $<1$ \\
1978 & Bluebunch wheatgrass & 55 & 45 & 10 & $<1$ \\
& Basin wildrye & 50 & 35 & 10 & $<1$ \\
\hline
\end{tabular}

Bluebunch wheatgrass $\hat{\mathrm{y}}=94.73-1.107 \mathrm{x} R^{2}=.940 t=9.695^{* *} P<.05$ Basin wildrye $\quad \hat{\mathrm{y}}=63.75-0.754 \mathrm{x} R^{2}=.818 t=5.19^{* *} \quad P<.01$ as primary routes of travel. Roads apparently played a key role in distribution of livestock, enabling them to travel easily through steep and broken country. Some use was made of vegetation near the roads in this terrain, but the distance at which utilization occurred decreased dramatically with increases in slope above or below the road. Cattle using these steep areas returned to the road to bed or rest. The roads had been seeded to orchardgrass (Dactylis glomerata), timothy (Phleum pratense), and intermediate wheatgrass (Agropyron intermedium) after logging and also provided a substantial amount of forage.

Roads in gentle terrain did not seem to be an important factor in distribution. Cattle trails in this terrain frequently did not follow a road, even when one was nearby. Preferred vegetation types such as pine uplands were not grazed when isolated by rough terrain with no road access. Williams (1954) and Workman and Hooper (1968) found that cattle distribution was greatly enhanced by roads or trail construction.

A characteristic pattern of cattle movement was demonstrated each year. Livestock were turned on the unit at one single gate. A road directed the cattle onto the riparian zone, where most of the cattle began grazing. After 7-10 days, livestock dispersed over the allotment to other preferred grazing areas. Approximately $35-40 \%$ of the cattle remained on the riparian zone for the duration of the season. Cattle seemed to congregate again on the riparian zone the last week of the grazing season.

\section{Cattle Behavior}

General patterns of herd movements on the unit were a reflection of a behavioral response. Turning the cattle in at a single point, especially where a primary route directed the animals onto a riparian zone, seemed to temporarily inhibit the formation of the grazing groups and prevented early dispersion of cattle onto other vegetation types. Arnold and Dudzinski (1978) described a typical exploring response of animals just moved to a new pasture. This did not occur with cattle in the study herd on this unit. Perhaps familiarity with the unit combined with the management influence precluded that response. Cattle which strayed in from a neighboring unit did display this typical exploring activity, moving at random through the unit and from group to group.

Three discrete groups of cattle formed on the unit. These groups were oriented to particular areas of the unit, similar to the "home range" groups described by wildlife biologists (Dasmann 1964). Analysis of individual movements indicated that approximately $44 \%$ of the herd formed a home range group which primarily used a pine uplands area away from the stream (Fig. 1). Distribution of this group was focused on three watering spots. Another home range group, comprising about $22 \%$ of the herd, localized in an area on the lower eastern portions of the unit. The remaining group primarily used the bluegrass bottoms and overlapped its home range boundary with both of the other two groups.

Substrata in each group were apparent. These substrata seemed to be tightly knit groups of individuals moving together within the framework of the entire home range group. The upland and the transition groups had three distinct subgroups, the east home range group had two. There was no real evidence to determine what factors controlled the animal associations in the substrata or in the home range group. These appear to be socially st ructured hierarchical groups. Elliott (1976) also found discrete groups of cattle on mountainous terrain. Hunter (1964) found home range behavior of sheep in hilly country in Scotland. He indicated that visual and topographic barriers caused a stronger social link between animals, creating home range groups. Behavioral scientists studying on flat or gentle terrain did not observe home range group formation (Dudzinski et al. 1969, Hodder and Low 1978, Lynch 1967). Range scientists have not recognized home range groups in work reported, but most observations were of cattle grazing gentle topography (Culley 1938, Herbel and Nelson 1966, Martin and Ward 1973, Moorefield and Hopkins 1951). Substrata of the home range groups seemed to move as a unit within the home 
Table 5. Results of regression analyses determining climatic parameter influence on cattle activities.

\begin{tabular}{|c|c|c|c|c|}
\hline Activity & Dependent variable & $\begin{array}{l}\text { Independent variables in order } \\
\text { of importance }\end{array}$ & $\begin{array}{l}\text { Variability } \\
\text { accounted for }\end{array}$ & Level of sig. \\
\hline \multicolumn{5}{|l|}{ BOTTOMS } \\
\hline \multirow[t]{3}{*}{ Morning grazing } & Time after sunrise & Relative humidity & 0.78 & 0.037 \\
\hline & & Relative humidity maximum & 0.98 & 0.002 \\
\hline & Regression Model & $\hat{y}=0.26 x_{1}+0.15 x_{2}-4.23$ & & \\
\hline \multirow[t]{4}{*}{ Morning bedding } & Time after sunrise & Temperature change & 0.78 & 0.039 \\
\hline & & Relative humidity change & 0.86 & 0.064 \\
\hline & & Relative humidity & 0.92 & 0.101 \\
\hline & Regression Model & \multicolumn{3}{|c|}{$\hat{y}=-0.26 x_{1}+0.58 x_{2}-0.60 x_{3}+11.70$} \\
\hline \multirow[t]{2}{*}{ Afternoon grazing } & Time after sunrise & Barometric pressure & 0.97 & 0.016 \\
\hline & Regression Model & $\hat{y}=-1.68 x+1085.6$ & & \\
\hline \multirow{4}{*}{$\begin{array}{l}\text { UPLANDS } \\
\text { Morning grazing }\end{array}$} & & & & \\
\hline & Time after sunrise & Relative humidity maximum & 0.89 & 0.041 \\
\hline & & Thermal humidity index & 0.95 & 0.089 \\
\hline & Regression Model & $\hat{y}=0.18 x_{1}-0.18 x_{2}-0.42$ & & \\
\hline \multirow[t]{5}{*}{ Morning bedding } & Time after sunrise & Relative humidity maximum & 0.53 & 0.026 \\
\hline & & Relative humidity change & 0.67 & 0.038 \\
\hline & & Relative humidity & 0.81 & 0.030 \\
\hline & & Temperature change & 0.98 & 0.007 \\
\hline & Regression Model & \multicolumn{3}{|c|}{$\hat{\mathrm{y}}=0.69 \mathrm{x}_{1}-0.92 \mathrm{x}_{2}-0.56 \mathrm{x}_{3}+0.15 \mathrm{x}_{4}+4.88$} \\
\hline
\end{tabular}

INDEPENDENT PARAMETERS CONSIDERED

$\left.\begin{array}{l}\text { Barometric pressure } \\ \text { Temperature }{ }^{\circ} \mathrm{C} \\ \text { Relative humidity } \\ \text { Thermal humidity index }\end{array}\right\}$

at the time the activity was observed

Temperature minimum

Temperature maximum

Temperature change

Relative humidity maximum

Relative humidity minimum

Relative humidity change

Thermal humidity index maxirnum

range area. Social linking between these individuals was not verified.

Size of the total areas used as a home range seemed to be consistent year to year; however, in 1977 the dry weather seemed to limit the amount of use in the peripheral areas distant from water. Cattle use was more uniform over the total area in 1978. Increased bedding time at the salt block apparently reflected less dependence on water. Moorefield and Hopkins (1951) reported similar observations, finding that when vegetation was succulent cattle spent less time near water.

Characteristic patterns of activities and movements were displayed by the animals. Individuals within subgroups showed considerable uniformity in the timing of activity and movement, although time when an activity occurred often was different between home range groups. This difference seemed to be in relationship to the area the group grazed, upland or meadow. The general pattern showed cattle would move from the bedding area shortly after sunrise and begin an active feeding period. This period varied in length but averaged about 3 hours. Cattle would generally bed in a shaded area until about midday, trail to water, drink, then bed in the shade near water. Shading up in the daylight hours rarely occurred on the riparian zone; cattle seemed to prefer adjacent slopes for bedding. If water and shade were near the grazing area, cattle would bed there after the morning active grazing period and remain in that area until mid or late afternoon. Lethargic grazing by some individuals, but rarely all the members of the groups, frequently occurred in mid-afternoon. During the late afternoon until sunset there was another active grazing period. Cattle stayed bedded from dark until sunrise. Areas chosen for night bedding by groups using the riparian zone were on adjacent slopes. Later in the season cattle grazed the steep south slopes in the evenings and bedded on those areas. Culley (1938), Gonzalez (1964), Hughes and Reid (1951), Sheppard et al. (1957), Sneva (1970), and Tribe (1950) reported similar patterns of activity.

Cattle behavior interacting with other a mbient factors produced a pattern of responses that determined activities, distribution, forage used, and herd structure. Discriminate analysis was used to determine the importance of elapsed time after sunrise and environmental parameters in predicting the probability of a specified activity occurring. Time after sunrise was the most important parameter and change in relative humidity the second most important in predicting the probability of a given activity occurring. Although those two parameters were significant, only $59 \%$ of the observations could be properly classified as to site and activity. Time after sunrise dictated the probability of the type of major activity occurring in that time frame. However, change in relative humidity altered the probability of predicting a particular activity during the beginning or end of the time frame. Dudzinski and Arnold (1979) and Hughes and Reid (1951) also found that the time after sunrise was an important factor in determining the time frame of activities. It seems logical that activities of cattle on a diurnal schedule would show a high relationship to time after sunrise. Other environmental parameters tend to change the timing or duration of the activities within a given time frame (Dudzinski and Arnold 1979).

Regression analysis indicated relative humdity parameters were principally responsible for the time when morning activities were initiated (Table 5). The thermal-humidity index (Ehrenriech and Bjugstad 1966) was not an accurate predictor of cattle grazing activities. One would assume physiological response to humidity 
parameters to be a response to humidity-temperature interaction, but in most cases temperature was not a significant factor accounting for variation in time when an activity occurred. Levels of significance were consistently higher using time after sunrise as a measure of the time an activity occurred than those using time after morning twilight as the dependent variable. Afternoon grazing was most related to barometric pressure; the total ramifications of this are not understood.

\section{Management Implications}

Management plans for grazing on mountainous ranges could be best formulated with detailed information about how cattle use those ranges and why cattle respond in a given manner. Cattle on the Camp Creek unit formed definitive home range groups of animals. These groups occupied the same home range area year to year. This suggested that the groups were semi-independent of each other. If this is so, cattle numbers could be manipulated in one group without substantially altering other groups. This could be especially valuable for the riparian zone which received a large percentage of the cattle use. Cattle which are known to be within the home range group on the bluegrass bottoms could be culled from the herd, decreasing the number of cattle on the bluegrass bottoms. Knowing which animals to cull in such a situation is contingent on knowing the herd structure and the individuals in each group.

Wildlife scientists have long known that many species will invariably return to their home ranges following disruption of their normal patterns, sometimes even after having been moved great distances. It seems unreasonable to herd cattle, which have developed a home range on the bluegrass bottoms, to an area away from there and expect them not to return to their home range. Skovlin (1957) reported that "cattle can be trained to use certain areas and will repeat that use year after year." It appears that livestock operators could take animals which have not grazed a unit before and behaviorally bond those cattle to a new area which had been previously under-utilized, given that water, forage, shade, and salt are available in that area. For this to be an effective management tool, the livestock must be handled so they disperse when turned on the pasture, avoiding initial concentration on the bluegrass bottoms.

These manipulations, however, must be consistent with other factors which control or limit grazing distribution. Water is an integral factor in determining where cattle will graze. Given that water is available, then other factors determine the amount of utilization and actual types which will be grazed. Trail building and other practices may be feasible. Some areas, because of extreme slopes or aspect, will continue to be avoided by cattle unless innovative vegetation or other management manipulations can be implemented.

\section{Literature Cited}

Arnold, G.W., and M.L. Dudzinski. 1978. Ethology of Free-Ranging Domestic Animals. Elsevier Sci. Pub. Co. N.Y. 198 p.

Carlson, G. 1974. Malheur National Forest soil resource inventory. Pacific Northwest Region. Soil Resource Inventory. U.S. Forest Serv. R-6 1944. $177 \mathrm{p}$.

Clary, W.P., P.F. Ffollitt, and F.R. Larson. 1978. Factors affecting forage consumption by cattle in Arizona ponderosa pine forests. J. Range Manage. 31:9-10.

Cook, C. Wayne. 1966. Factors affecting utilization of mountain slopes by cattle. J. Range Manage. 19:200-204.
Culley, M.J. 1938. Grazing habits of range cattle. J. Forest. 36:715-717. Dasmann, R.F. 1964. Wildlife biology. John Wiley and Sons, Inc. N.Y. 231 p.

Dudzinski, M.L., and G.W. Arnold. 1979. Factors influencing the grazing behavior of sheep in a Mediterranean climate. Applied Anim. Ethol. 5:125-143.

Dudzinski, M.L., P.J. Paul, and G.W. Arnold. 1969. Quantitative assessment of grazing behavior of sheep in arid areas. J. Range Manage. 22:230-235.

Ehrenriech, J.H., and A.J. Bjugstad. 1966. Cattle grazing time related to temperature and humidity. J. Range Manage. 19:141-142.

Elliott, J.C. 1976. Diet and feeding behavior of cattle at risk to dietary acute bovine pulmonary emphysema (DABPE). M.S. Thesis. Oregon State Univ. 125 p.

Gonzalez, Martin H. 1964. Patterns of livestock behavior and forage utilization as influenced by environmental factors on a summer mountain range. Ph.D. Diss. Utah State Univ. 151 p.

Hedrick, D.W., J.A. Young, J.A.B. McArthur, and R.F. Keniston. 1968. Effects of forest and grazing practices on mixed coniferous forests of northeastern Oregon. Agr. Exp. Sta. Tech. Bull. 103. 23 p.

Herbel, C.H., and A.B. Nelson. 1966. Activities of Hereford and Santa Gertrudis cattle on a southern New Mexico range. J. Range Manage. 19:173-176.

Hodder, R.M., and W.A. Low. 1978. Grazing distribution of free-ranging cattlc at three sites in the Alice Springs District, Central Australia. Austr. Rangeland J. 1:95-105.

Hughes, G.P., and D. Reid. 1961. Studies of the behavior of cattle and sheep in relation to the utilization of grass. J. Agr. Sci. 41:350-366.

Hunter, R.F. 1964. Home range behavior of hill sheep. In: D.F. Crisp (Ed.), Grazing in Terrestrial and Marine Environments. Blackwell, Oxford. p. 155-170.

Lynch, J.J. 1967. Ranging behavior of sheep in large areas. Proc. Austr. Ecol. Soc. 2:167-169.

Martin, S.C., and D.E. Ward. 1973. Salt and meal-salt help distribute cattle use on semi-desert range. J. Range Manage. 26:94-97.

Miller, R.F., and W.C. Krueger. 1976. Cattle use on summer foothill rangelands in northeastern Oregon. J. Range Manage. 29:367-371.

Moorefield, J.G., and H.H. Hopkins. 1951. Grazing habits of cattle in a mixed prairie pasture. J. Range Manage. 4:151-157.

Mueggler, W.F. 1965. Cattle distribution on steep slopes. J. Range Manage. 18:255-257.

Patton, W.W. 1971. An analysis of cattle grazing on steep slopes. M.S Thesis. Brigham Young University, Utah. $42 \mathrm{p}$.

Phillips, T.A. 1965. The influence of slope gradient, distance from water and other factors in livestock distribution on National Forest cattle allotments of the Intermountain Region. U.S.D.A. Forest Serv. Intmtn. Forest and Range Exp. Sta. Range Impr. Notes. 10:9-19.

Sheppard, A.J., R.E. Blaser, and C.M. Kincaid. 1957. The grazing habits of beef cattle on pasture. J. Anim. Sci. 16:681-687.

Skovlin, J.M. 1957. Range-riding-The key to range management. J. Range Manage. 10:269-271.

Sneva, F.A. 1970. Behavior of yearling cattle on Eastern Oregon range. J. Range Manage. 23:155-158.

Tribe, D.E. 1950. The behavior of the grazing animal: A critical review of present knowledge. J. Brit. Grassland Soc. 5:209-224.

United States Senate. 1936. The Western Range. Senate Document 199. 74th Congress, Second Session. $620 \mathrm{p}$.

Van Vuren, D. 1979. Ecology and behavior of bison in the Henry Mountains, Utah. M.S. Thesis, Oregon State Univ. 39 p.

Williams, R.E. 1954. Modern methods of getting uniform use of ranges. J. Range Manage. 7:77-81.

Wilm, H.G., D.F. Costello, and C.E. Klipple. 1944. Estimating forage yield by the double-sampling method. J. Amer. Soc. Agron. 36:194-203.

Workman, J.P., and J.F. Hooper. 1968. Preliminary economic evaluation of cattle distribution practices on mountain rangelands. J. Range Manage. 21:301-304. 